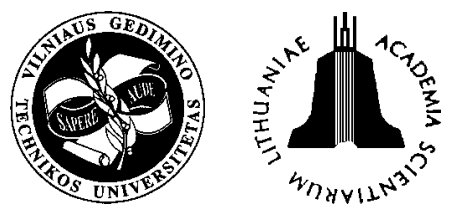

ISSN 1648-4142 TRANSPORT

http:/www.vtu.lt/english/editions

TRANSPORT - 2004, Vol XIX, No 5, 224-229

\title{
THE INFLUENCE OF TERRITORY PLANNING AND SOCIAL DEVELOPMENT ON STRATEGIC DECISIONS IN PASSENGER TRANSPORT DEVELOPMENT
}

\author{
Daiva Griškevičienė, Algirdas Griškevičius \\ Dept of Transport Management, Vilnius Gediminas Technical University, \\ Plytinès g. 27, LT-10105 Vilnius-16, Lithuania.E-mail: daiva1@centras.lt
}

Received 2004-02-07; accepted 2004-06-30

\begin{abstract}
The main factors of space planning and social development which play an important role in making strategic decisions in passenger transportation have been analysed. A number of strategic aims based on major principles of territory transport planning have been formulated. The investigation made has shown that the operation of public transport is not closely connected with the main carcass of urban territories. This decreases the efficiency of public transport, making it less popular and competitive compared to automobiles.

The creation of the strategy of public transport development for the period of its integration into the EU system requires the use of methods taking into account territory planning and social and economic development of the country. The integration of new territories into the existing transportation system, optimization of routes and the increase of transport service quality are aimed to provide higher living standards and better social and economic conditions for the inhabitants. The appropriate tactical decisions in planning the development of modern passenger transport may be made only if the harmonized and well-grounded strategic aims are defined.

Keywords: passenger route transport; transport mobility; spatial development; sustainable territorial transport service; strategic goals; tactical decisions.
\end{abstract}

\section{Introduction}

The prospective development of passenger transport is closely connected with the location of industrial enterprises and residential areas on particular territories of the country as well as with its economic development. Therefore, the development of transport services and the infrastructure is aimed at creating such a system of services that could satisfy the needs of national industry, recreation and cultural heritage preservation by ensuring territory, social and cultural development and the creation of the infrastructure and an optimal urban system, preserving, at the same time, the landscape and the variety of biological species on a particular territory.

The analysis of passenger traffic in Lithuania has shown that the development of this system is not always considered in the framework of territory development, which causes a number of negative effects. Some insignificant tactical decisions made in developing transportation on some routes of particular regions and towns do not follow a general strategic plan either because of its absence or ignorance. This is especially typical of towns and small settlements where social, economic and transportation models have changed giving the priority to new factors determin- ing the choice of transport facilities and the use of the infrastructure. Therefore, in developing the appropriate strategy of passenger transportation, space planning and social development should be taken into account.

\section{Major strategic goals of territory development}

In developing passenger transportation strategy major goals within the concept of social and territory development should be determined. Transportation is one of the systems aimed to provide services to the inhabitants of a particular territory, which should be developed in accordance with the priorities stated for social and economic development of this territory and its main functions.

To maintain the balanced development of a territory, its social and economic development should rely on the following principles: to maintain the potential of the territory and to provide the qualitatively new coordination of the territory's development, preserving its unique nature and protecting the environment in the process of integration into the European social, cultural and economic structures. Higher living standards of the population may be achieved by 
improving social, cultural and economic conditions as well as services and the infrastructure [1]. The economic growth of the country may be stimulated by the development and liberalization of free market relations, coordinating the activities according to the specific nature of the territory. Healthy environment may be ensured by taking special environment protection measures and applying the environmentallyfriendly technologies. This implies that social, economic and ecological problems of the country should be harmonized (Fig 1) [2].

1. In the social context harmonized goals of territory planning are associated with the differentiation of demographic and social development with respect to a particular area implementing the programs of the location of industrial enterprises and settlements and the creation of new working places. This is the only way to ensure uniform development of various areas and reinforce their cultural identity and self-government institutions.

2. In the economic context harmonized goals of territory planning are associated with the development of small and medium-size businesses and trades, traditional agriculture and forestry for making ecological products and using the alternative sources of power. It also means the development of rural tourism and recreation zones taking into account the specific conditions of particular territories and new market possibilities as well as turning the sea-coast into the area of recreation, fish-breeding and sea transport development.
3. In the environment protection context effective programs of controlling, rational use and protection of the landscape, cultural heritage aimed to preserve the unique features of a particular territory should be implemented.

Therefore, the development of the state territories should be based on:

- harmonious and purposeful development of a network of settlements relying on the existing layout of towns and uniform distribution of centers of activities.

- optimization of regionalization of national territories according to the EU standards, providing the established regions with a tool of planning and pursuing regional policy and taking all necessary actions to improve the situation, if any negative effects of development manifest themselves.

- a considerable increase of investments into the most problematic areas.

\section{Major strategic goals of social development}

With respect to harmonization of social interests, strategic and tactical solutions in the area of passenger transportation should be made following some important principles given below.

1. To ensure the continuity of development, the present generation makes efforts to produce longterm forecasts to create an advanced modern transport system and to use the environmentally-friendly

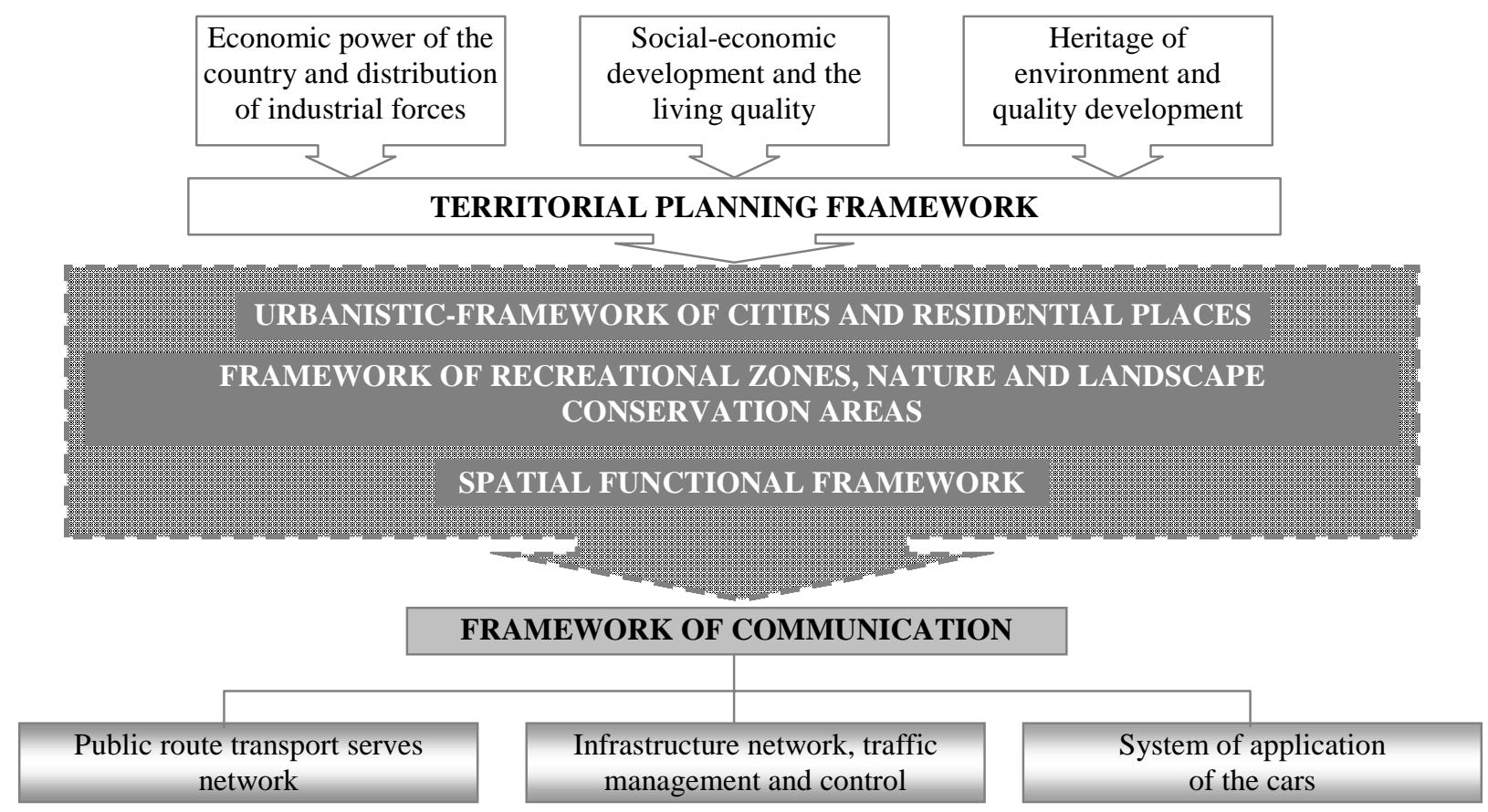

Fig 1. Transport communication framework connection with territorial planning basic framework 
technologies so as to leave a good heritage to the next generations.

2. Strategic and particularly tactical decisions made in transport should be based on professional forecasts as well as on research and practical experience which would help to determine their possible positive and negative effects.

3. An acceptable living standard should be maintained in society for all citizens and juridical persons, which has been declared as the government's concern and responsibility.

To ensure social and economic welfare of the inhabitants the division of territories and the creation of the network of settlements is being planned. The existing hierarchical multiple centre network of inhabited areas should be based on the criterion of harmonizing passenger transport services in all settlements, regional centres and towns. Therefore, the appropriate infrastructure and its efficient use are the main factors determining effective transportation all over the country.

The networks of the infrastructure and services differentiated with respect to particular regions and areas provide a possibility to harmonize the trends of concentration and spreading of urban population and to reinforce the weak links in the network of settlements. This, in turn, could help to raise the quality of life of the inhabitants. Such policy well agrees with the concept of sustainable development adopted in Europe. The network of the inhabited urban areas of Lithuania should naturally integrate into the hierarchical urban system created in Europe. Transport system is given a high priority in this process.

The development and upgrading of transport system is also closely connected with environmental problems caused by technological activities, pollution, exhaust gases from transport facilities, the pollution of sea, river and lake water with oil products, noise pollution in large cities caused by vehicles and the problems of sustainabi-lity. Ecological stability is one of the main factors for the society and technical infrastructure and their activities. Therefore, the policy of transport development as one of the main driving forces of social and industrial development should be environmentally-oriented.

To improve the conditions for social activities and business, a system of transport which could help to develop harmonized business, to ensure the spread of small and medium-size businesses on all inhabited territories of the country which could help it to integrate into the EU economic system with minimum expenses should be created. A national transport system and its infrastructure should comply with the principles of harmonization of production and environment protection interests to contribute to the forma- tion of an integral system of land use and the uniform spreading of agricultural enterprises producing bioproducts over different territories, and to stimulate the creation of specialized recreation areas and tourism $[3,4]$.

The creation of social and cultural infrastructure associated with the development of territories requires an effective system of passenger transportation over the country and in metropolitan and regional centres.

It is planned that the future complex development of passenger transport system will require the following measures to be taken:

- to create a unified Lithuanian transport system satisfying the needs of transportation in particular regions and in the country as a whole, taking advantage of international transport networks for internal passenger transportation and separating transport services from the infrastructure;

- to maintain harmonized development of the national transport network by using the available infrastructure of various transport facilities, decreasing their harmful effect on the environment and increasing speed and comfort of travel at an economical cost.

- To integrate Lithuanian transport system into the European network of transport market services as well as into the Baltic sea region system taking advantage of the geographical and geopolitical position of Lithuania.

\section{Major strategic goals of territory integration}

The integration of Lithuanian transport system into the European space should rely on political, economic, social and environmental aspects. The policy of supporting regional integration of Northern Europe and the Baltic states should be the priority item in order to maintain good social and economic relations and close cooperation with the neighbouring countries of the region.

The strategy of territory development in Lithuania is based on the following general principles adopted by the European Union in this area:

2) social and economic development relies on the formation of harmonized territory structures;

3) territory (space) structures are based on specific valuable features and regional identity in the European context;

4) economic development is not in conflict with the policy of rational use and protection of cultural heritage and the environment.

The integrated territory of Europe is formed according to various models taking account of the strategic decisions of individual states. Basing itself on major international and the EU standards of strate- 
gic planning, Lithuania should observe the following principles in developing the national transport system:

- to work out the strategy of harmonized transport system development complying with a general national plan of territory development;

- to harmonize transport development with the multiple centre system of inhabited areas and their infrastructure within a concept of territory development of the country;

- to give the priority to international transport corridors in planning the development of transport infrastructure and major zones of its influence;

- to raise the economic level and competitiveness of the frontier and transit areas;

- to improve the planning system of transport development and the compiling of documents relating to transportation in the European Baltic sea region;

- to make tactical decisions on the development of transport infrastructure in proper time;

- to solve the problems associated with crossing the borders and the creation of the infrastructure;

- to create and to follow the sustainable strategy of providing passenger transport services over the territory of the country, thereby improving living conditions of the population of particular regions;

- to reinforce the institutions planning and providing transport services to enable them to achieve the outlined aims;

- to effectively use the EU structural funds in pursuing major goals of regional policy.

\section{Major strategic goals of harmonized development of transport system}

To attain the strategic aims stated below the compe-titiveness of national transport should be increased to match the possibilities of West European regions. Both economically and ecologically stronger and weaker regions should be supported by reinforcing the mecha-nisms of realization of the adopted strategy (Fig 2).

Transport system of Lithuania should be developed in compliance with the existing hierarchical multiple centre network of inhabited areas by integrating local, continental and global level systems:

- our country is connected to transcontinental transport network via the first-order EU and continental transport network;

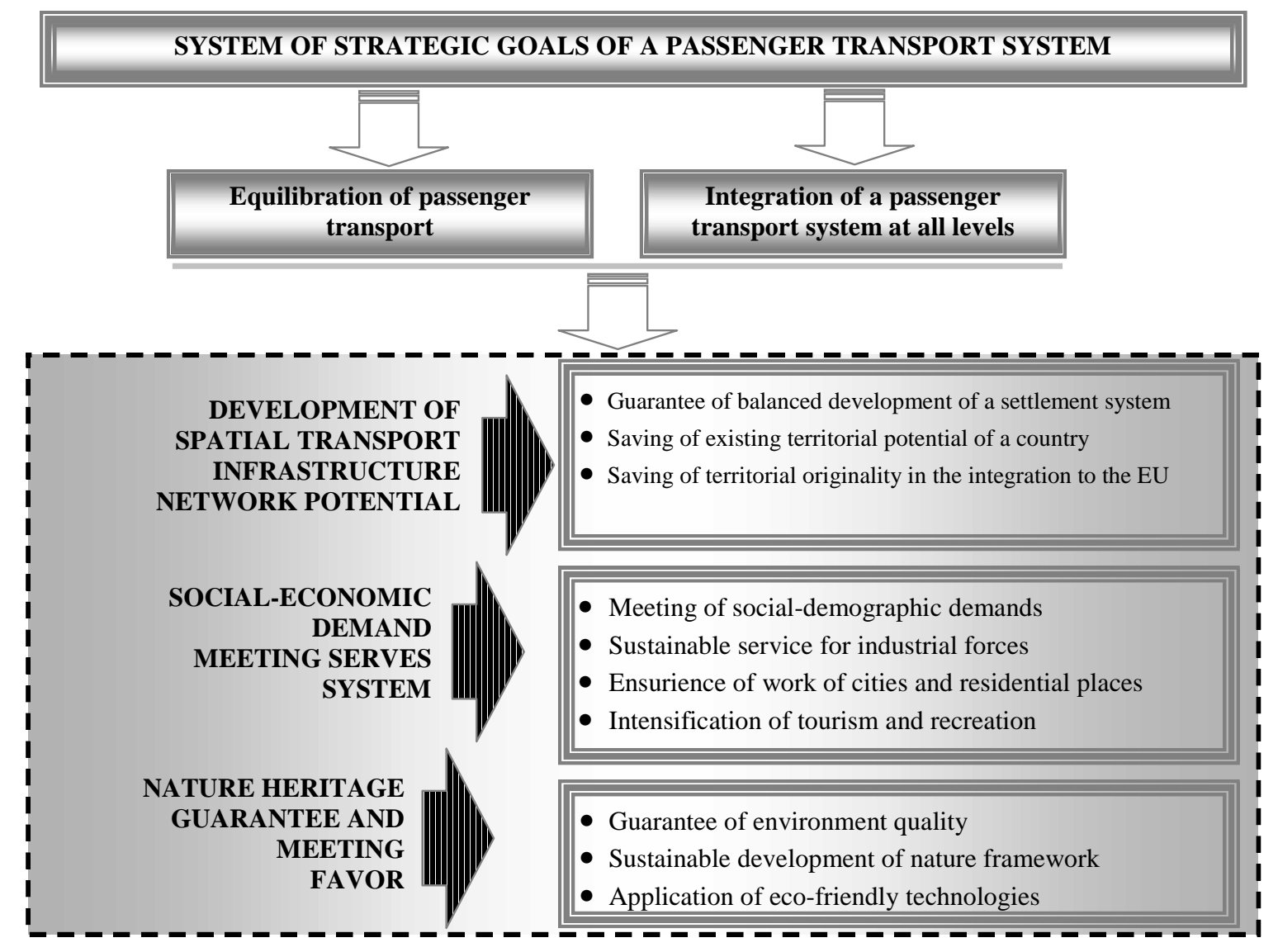

Fig 2. The strategic goals structure of a passenger transport system 
- first-order network of transport infrastructure connecting regional centres directly links Lithuania to the European continental network by common European corridors;

- the network of international-national infrastructure links second-order regional centres to the first level network;

- the network of regional infrastructure connects third-order regional centres linking them to higher level networks;

- the networks of the local transport infrastructure supplement a basic system connecting the firstthird level urban centres.

At the macro-level, passenger transport network should be linked to the international trans-European transport corridors passing through the territory of Lithuania which are as follows:

- the multimodal transport corridor I - Via Baltica (Helsinki - Tallinn - Kaunas - Warsaw);

- the multi-corridor IA - Via Hanseatica (Riga Kaliningrad - Gdansk);

- the road IXB and railway corridor (Klaipda Vilnius - Minsk - Moscow - Kiev - Bucharest Dimitrograd - Aleksandropol);

- the road IXD and railway corridor (Kaunas Kaliningrad).

At the local level, passenger transport should serve a multiple centre system of inhabited areas, harmonizing urban-rural territory relationships making the infrastructure available to the inhabitants, supporting social and economic development of the country and rational use and preservation of land and cultural heritage.

At the level of large urban centres, efforts should be made to harmonize services provided by various transport facilities to all inhabited areas and the development of the capacity of their infrastructure.

\section{Major strategic goals of passenger transport de- velopment}

To provide passenger transport services to the whole territory of the country it is planned to take the following actions:

- to encourage the local inhabitants to use public transport;

- to increase the quantity and quality of Lithuanian public transport services so that they could match the level of passenger transportation attained in the advanced EU member-countries;

- to create a balanced financing mechanism of public passenger transport which could be competitive under market conditions;

- to develop a network of public transport routes capable to satisfy the needs of passengers over the whole territory;

- to encourage the competition of urban passenger transport enterprises providing services to the inhabitants;

- to authorize the municipalities to solve the problems of transportation connected with planning, development, financing and quality control of transport services;

- to introduce and promote the interaction of various transport facilities engaged in passenger transportation;

- to complete the restructuring of the system determining market relations of transport sector in Lithuania;

- to integrate Lithuanian operators and forwarders of passenger transport facilities into the market of transport services of the Baltic sea region and continental Europe;

- to extend international routes by effectively using the capacities of modernized European transport corridors I and IX;

- to modernize passenger terminals and services they provide;

- to complete the harmonization of the legislative base of passenger transportation with the EU requirements;

- to develop a safe and environmentally-friendly transport system.

The following tactical scheme should be implemented in order to harmonize the development of passenger transportation in Lithuanian cities:

- to use effectively the existing roads and to introduce modern methods of traffic organization and control to take full advantage of the carrying capacity of roads;

- to ensure the mobility of passengers by using more powerful passenger transport facilities, restricting the use of automobiles, uniformly spreading their parking places, avoiding traffic bottlenecks at crossings and providing good transport services;

- to provide transport services to all areas of the city, decreasing the use of private automobiles, increasing transport services to handicapped passengers and providing passengers with route options in the old and newly built districts of the city;

- to locate car parking placed near transport terminals and transfer points;

- to guarantee higher safety of people, decreasing the number of car accidents and casualties on the road;

- to reduce air and noise pollution by vehicles and 
to restrict or ban traffic in "vulnerable" city areas;

- to improve transport services provided to lowincome and handicapped people, thereby reducing the gaps between various social groups associated with transport problems;

- to introduce and develop information technologies to decrease the need of the inhabitants for travel both by public or private transport facilities;

- to develop transport services in such a way as to protect the centre or old town of the city as well as new "bedroom" districts and recreation zones, encouraging, however, the use of public transport;

- to create a mechanism for project development, evaluation and implementation, as well as land reservation, determination of costs and investments in developing urban transport systems.

\section{Conclusions}

To pursue the strategy of developing a sustainable harmonized passenger transportation and to create an integral system of transport routes, both in the country and particular cities, the following aims should be attained:

1) to introduce an integrated system of passenger transportation by coordinating the use of vehicles and marketing of transport services as well as selling of tickets and information about the available services;

2) to develop a system which would integrate various transport facilities, harmonize and coordinate transport services provided by them, use their potential and maintain intermodal operation, combining services provided by public and private transport;

3) to consider transport development as one of the problems associated with general social and economic development of the city.

\section{References}

1. A general territory development plan of the Republic of Lithuania. Ministry of Environment Protection of Lithuania (LR bendrasis teritorinis planas), 2002 (in Lithuanian).

2. Juškevičius, P. Harmonization of the urban transport systems. Monograph (Miestų ir jų susisiekimo sistemų plètros harmonizavimas). Vilnius: Technika, 2003 (in Lithuanian).

3. Transport: technologies, economics, environment, health. A collective monograph (Transportas: technologijos, aplinka, sveikata). Vilnius: Technika, 2003. 876 p. (in Lithuanian).

4. Griškevičiene, D.; Griškevičius, A. Social and economic analysis of the demand for public transport in Vilnius. Transport, Vol XVIII, No 4, Vilnius: Technika, 2003, p. 182-188. 